\title{
電解析出ナノ結晶 $\mathrm{Ni}-\mathrm{W}$ 合金の疲労特性
}

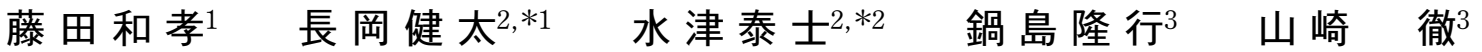 \\ 1宇部工業高等専門学校機械工学科 \\ 2 宇部工業高等専門学校専攻科生産システム工学専攻 \\ 3 兵庫県立大学大学院工学研究科
}

J. Japan Inst. Met. Mater. Vol. 77, No. 5 (2013), pp. 192-197

(C) 2013 The Japan Institute of Metals and Materials

\section{Fatigue Properties in Electrodeposited Nanocrystalline Ni-W Alloy}

\author{
Kazutaka Fujita ${ }^{1}$, Kenta Nagaoka ${ }^{2, * 1}$, Taiji Suidu²,*2, Takayuki Nabeshima ${ }^{3}$ and Tohru Yamasaki ${ }^{3}$ \\ ${ }^{1}$ Department of Mechanical Engineering, Ube National College of Technology, Ube 755-8555 \\ ${ }^{2}$ Advanced Course of Production System Engineering, Ube National College of Technology, Ube 755-8555 \\ ${ }^{3}$ Graduate School of Engineering, University of Hyogo, Himeji 671-2280
}

\begin{abstract}
The nanocrystalline Ni-W alloy fabricated by an electrodeposition method has a high-strength and high-bending ductility. However, its fatigue properties are not known yet. Therefore, fatigue tests were carried out to clarify the fatigue properties. Nanocrystalline $\mathrm{Ni}-\mathrm{W}$ alloy specimens containing 16.9 at\% W with about $20 \mu \mathrm{m}$ in thickness, $200 \mu \mathrm{m}$ in parallel part length, and $100 \mu \mathrm{m}$ in width were produced by both UV photolithography and electrodeposition methods. The average grain size was about 6 $\mathrm{nm}$ in diameter and the tensile strength was about $2.8 \mathrm{GPa}$. The fatigue test was conducted at a stress ratio of 0.1 and a frequency of $10 \mathrm{~Hz}$. The fatigue limit and fatigue ratio showed $2.1 \mathrm{GPa}$ and 0.74 , respectively. Macroscopic fractured morphology showed no necking and perpendicular fracture for the loading axis. However, microscopic fracture surface showed flat and featureless morphology at near the crack initiation region and it showed striations from the region where the striation spacing became more than about $10 \mathrm{~nm}$. The final unstable fracture surface showed dimples with a diameter of $100 \sim 200 \mathrm{~nm}$.

[doi:10.2320/jinstmet.J2012067]
\end{abstract}

(Received November 14, 2012; Accepted February 26, 2013; Published May 1, 2013)

Keywords: nanocrystalline nickel-tungsten alloy, fatigue, ultraviolet (UV) photolithography, electrodeposition methods, fractography

\section{1. 緒言}

電解析出法により作製された純 $\mathrm{Cu}$ や純 $\mathrm{Ni}$ などのナノ結 晶材は，それぞれ延性や強度に優れているとする報告があ る1,2)が，それらは熱的安定性に乏しい3). また，同法により 作製されたナノ結晶合金やアモルファス合金の多くは，熱的 安定性は増すが脆いことが知られている4). 著者の一人らに より開発された電界析出ナノ結晶 $\mathrm{Ni}-\mathrm{W}$ 合金 ${ }^{5,6)}$ は, 熱的安 定性と高硬度・高勒性 ${ }^{6-8)}$ を有する. 硬度は結晶粒径を約 15 $\mathrm{nm}$ まで微細化するとホールペッチ則に従って上昇し, さら に微細化すると軟化現象が見られ，これは結晶粒界の占める 体積率の著しい増加に起因するとされている ${ }^{5-7)}$. 引張試験 も, 平均結晶粒径が $3 \mathrm{~nm}$ を有する $\mathrm{Ni}-20.7 \mathrm{at} \% \mathrm{~W}$ 合金をワ イヤカット放電加工機で平行部幅 $2 \mathrm{~mm}$, 長さ $5 \mathrm{~mm}$ の試験 片に加工して実施され, 引張強さ $\left(\sigma_{\mathrm{B}}\right)$ は最大 $2.3 \mathrm{GPa}$ と高 強度を示したことが報告されている7).さらに，フォトリソ

\footnotetext{
*1 宇部工業高等専門学校専攻科生 (Advanced Course Student, Ube National College of Technology)

*2 宇部工業高等専門学校専攻科生, 現在: 三菱重工業侏 (Advanced Course Student, Ube National College of Technology, Present address: Mitsubishi Heavy Industries, Ltd.)
}

グラフィ法と電解析出法を組み合わせることにより，材料創 性と上記と同一形状の試験片成形を同時に行った結晶粒径が $10 \sim 20 \mathrm{~nm}$ を有する $\mathrm{Ni}-16.9 \mathrm{at} \% \mathrm{~W}$ 合金では， $\sigma_{\mathrm{B}}$ が 1.7 $\mathrm{GPa}$ を示したことが報告されている ${ }^{9)}$. 本材料はフォトリソ グラフィ法と電解析出法で作られるため, 上記試験片寸法よ りも微小な寸法の部材を高精度で作製できるため微小強度部 材として有望である. そこで, 同法を用いて結晶粒径が約 6 $\mathrm{nm}$ を有する $\mathrm{Ni}-16.9$ at $\% \mathrm{~W}$ で, 平行部幅 $50 \mu \mathrm{m}$, 長さ 4 $\mathrm{mm}$, 厚さ $20 \mu \mathrm{m}$ の小試験片を作製し引張試験を行った結果, $\sigma_{\mathrm{B}}$ は平均約 $2.8 \mathrm{GPa}$ とさらに高強度を示した ${ }^{10)}$. しかし, 実用上重要となる疲労特性については未だ知られていない。 そこで本研究では, ナノ結晶 $\mathrm{Ni}-\mathrm{W}$ 合金について, 繰返 し応力下の疲労試験を行い, 疲労特性を調べるとともに, 破 壊機構をフラクトグラフィー的に検討する.

\section{2. 試 験 方 法}

試験片は, 紫外線フォトリソグラフィ法と電解析出法を用 いて作製したナノ結晶 $\mathrm{Ni}-16.9$ at\% $\mathrm{W}$ 合金であり, $6 \mathrm{~nm}$ 程 度の結晶が均一に分布した材料である ${ }^{9,10)}$. 結晶構造は放射 光による X 線吸収端微細構造解析 (EXAFS)の結果, $\mathrm{Ni}_{4} \mathrm{~W}$ 型の結晶物構造に近い原子配列になることが分かってきてい 
る11).ビッカース硬さは $5.5 \mathrm{GPa}$ である12,13).

試験片の形状㧍よび寸法を Fig. 1 に示す。平行部長さは $200 \mu \mathrm{m}$ ，幅は $100 \mu \mathrm{m}$ であり，試験部両側表面は＃2000の 研磨紙で研磨した後, ラッピングフィルムで＃4000を経て \# 8000 まで試験結果に影響を及ぼさぬよう荷重軸方向に研 磨した。研磨後の厚さは約 $12 \mu \mathrm{m}$, 幅は約 $94 \mu \mathrm{m}$ である.

Fig. 2 に試験片表側の研磨後の表面写真例を示す。研磨後の 表面粗さ $(R a)$ は，3D 測定レーザー顕微鏡 (OLYMPUS LEXT OLS4000)を用い試験片平行部の研磨方向に垂直に粗 さ解析を行った. その結果, カットオフ值 $8 \mu \mathrm{m}$, 表面側の 評価長さ $90 \mu \mathrm{m}$, 側面側の評価長さ $10 \mu \mathrm{m}$ に対して, Raは それぞれ約 $0.02 \mu \mathrm{m}$ と約 $0.05 \mu \mathrm{m}$ であった.

試験後, 走査型電子顕微鏡 $(\mathrm{FE}-\mathrm{SEM}$; 日立 S-4300Y)に より破断した試験片の破断部を荷重軸方向から 2000 倍で撮 影し(読取誤差 $\pm 0.2 \mu \mathrm{m}$ ), 破断個所の面積と遠方の断面積 を求め, それぞれを真破断面積掞よび初期断面積として応力 を計算した。

疲労試験は, 電磁力サーボ式微小荷重試験機 (島津製作所 MMT-10N) を用い常温大気中において, 応力比 $R=0.1$ の 部分片振り, 繰返し速度 $10 \mathrm{~Hz}$ で実施した. 指示值に対す る実働值の比は平均值が $+0.3 \sim-0.5 \%$, 振幅值が $+0.5 \sim$ $-1.4 \%$ であった。

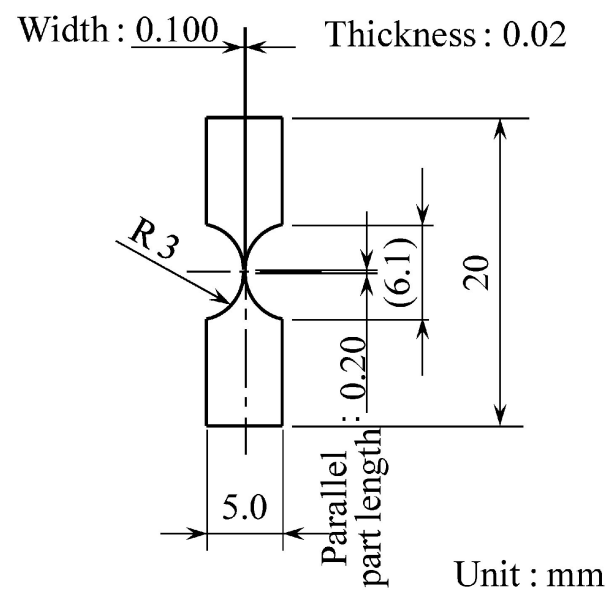

Fig. 1 Configuration and sizes of test specimen.
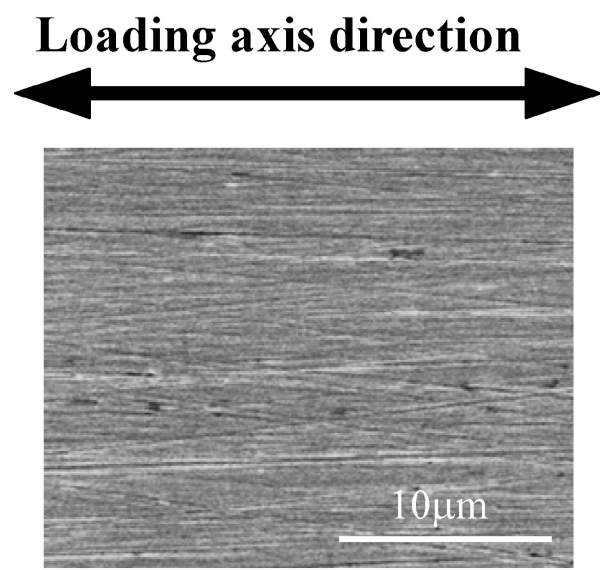

Fig. 2 Scanning electron micrographs on the specimen surfaces after polishing.
試験片の試験機への取付けは，試験片が非常に薄く，幅も 狭いので取付け時に試験片に過負荷がかからないよう十分に 注意しながら, 試験片固定具に試験機と試験片の芯が一致す るように行った。

疲労限度 $\left(\sigma_{\mathrm{w}}\right)$ は, $2 \times 10^{6}$ 回まで一定応力振幅を繰返し負 荷し，破断しなかった試験片に負荷された最も大きい全応力 振幅 $\left(2 \sigma_{\mathrm{a}}=\sigma_{\max }-\sigma_{\min }\right)$ と, それ以下の繰返し回数で破断し た試験片に負荷された最も小さい $2 \sigma_{\mathrm{a}}$ の中間值とした。 た，一部，そのようにして求めた疲労限直下の $2 \sigma_{\mathrm{a}}$ を $1 \times$ $10^{7}$ 回まで繰返し負荷し, $2 \times 10^{6}$ 回以上に扔いて疲労破壊を 生じないことを確認した. 破断および未破断試験片の観察は 上記 SEM および HR-SEM(日立 SU8000)を用いて行った.

\section{3. 結 果 と検 討}

Fig. 3 に $S-N$ 曲線を示す. 縦軸および横軸は, それぞれ $2 \sigma_{\mathrm{a}}$ と破断までの応力繰返し数 $\left(N_{\mathrm{f}}\right)$ の対数でり, $\sigma_{\mathrm{w}}$ は 2.1 $\mathrm{GPa}$ である.この $\sigma_{\mathrm{w}}$ は, 高強度結晶合金で高疲労限度を有 する $\mathrm{Cr}-\mathrm{Mo}$ 鋼 (JIS SCM435)の $\sigma_{\mathrm{w}}=1.0 \mathrm{GPa}^{14}$ ) や合金工具 鋼 $\left.(J I S ~ S K D 61) の \sigma_{\mathrm{w}}=0.9 \mathrm{GPa}^{15}\right)$ の 2 倍程度と極めて大き な值である。

また, Fig. 3 の縦軸の $2 \sigma_{\mathrm{a}}$ を $\sigma_{\mathrm{B}}$ で除した值 $\left(2 \sigma_{\mathrm{a}} / \sigma_{\mathrm{B}}\right)$ で $S-$ $N$ 曲線を描いてみると, 耐久比 $\left(\sigma_{\mathrm{w}} / \sigma_{\mathrm{B}}\right)$ は 0.74 であった。 これも高強度結晶合金で高耐久比を有する $\mathrm{Cr}-\mathrm{Mo}$ 鋼 $\left.(\mathrm{SCM} 435) の \sigma_{\mathrm{w}} / \sigma_{\mathrm{B}}=0.51^{14}\right)$ や合金工具鋼 $(\mathrm{SKD} 61) の \sigma_{\mathrm{w}} /$ $\left.\sigma_{\mathrm{B}}=0.4915\right)$ を大幅に超える大きな值を示した.

ただし, 今回使用した試験片は寸法が小さいので, 軸力試 験とは言え， $\sigma_{\mathrm{w}}$ に寸法効果が生じる可能性が考えられる. この原因としては，試験片寸法が大きくなると電析時に生じ る気泡等の欠陥が材料に含まれる確率が増えること, また試 験片寸法が小さいほど断面積に占める, 内部より変形しやす いと考えられる表面の面積の割合が増えることなどが想定さ れる．両者はいずれも $\sigma_{\mathrm{w}}$ を低下させる可能性がある．特に 後者は学術的な興味が持たれ，今後，欠陥のないより大きな 試験片の作製を試み, 軸力片振り引張応力下の微小な試験片 の寸法効果がぞの程度のものであるかを明らかにしておくこ

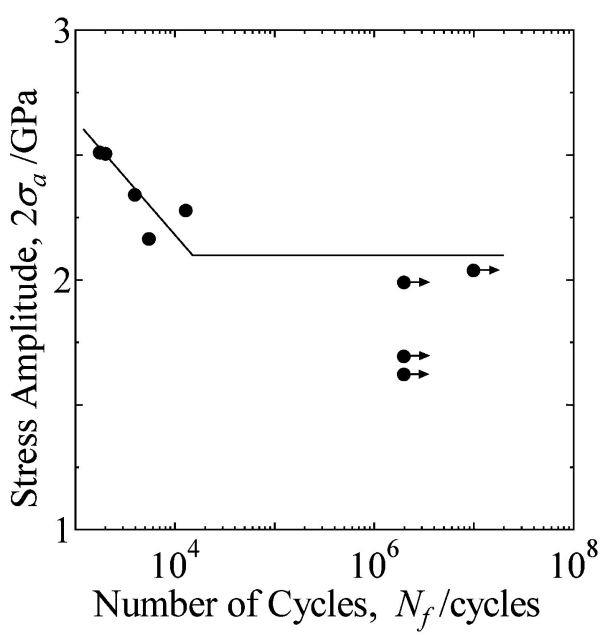

Fig. $3 S-N$ curve in the nanocrystalline Ni-W alloy. 
とが必要と考えられる。

疲労限度直下 $\left(2 \sigma_{\mathrm{a}} / \sigma_{\mathrm{w}}=0.97\right)$ の応力を $10^{7}$ 回負荷後, 試験 を中断した試験片表面の平行部全領域を FE-SEM で詳細に 観察したが, せん断帯やき裂は観察されなかった.

破断したすべての試験片の疲労き裂は荷重軸に対してほぼ 垂直に成長し, 破断していた。Fig. 4 に荷重軸方向から FE-SEM で撮影した巨視的破面写真例 $\left(2 \sigma_{\mathrm{a}} / \sigma_{\mathrm{w}}=1.04\right)$ を示 す. 破面上には荷重軸に垂直な疲労き裂発生部と, それに続 く伝ぱ部，および不安定破壊部が観察される。 また，ネッキ ングも生じておらず，ナノ結晶 $\mathrm{Ni}-\mathrm{W}$ 合金は巨視的には脆 性的に破壊することが分かる.

Fig. 5 にき裂発生部付近の拡大写真を示す. 図中の矢印は き裂伝ぱ方向を示している. 発生起点に明確な欠陥は見られ ず，き裂の発生はコーナー付近である，発生からそれに引続 く初期き裂伝ぱ領域は平坦で無特徵な様相を示している.

Fig. 6 に疲労き裂伝ぱ部と不安定破壊部と見られる領域の 境界付近の写真を示す。同図に記した白い破線部分が境界で ある.この境界後方 (Fig. 5 の A 部)を拡大したマッチング 写真例を Fig. 7 に示す. これらの図より明らかなように, 境界付近までき裂が成長して，応力が大きくなると，破面は 縞模様とディンプル状の模様から成ることが分かる. Fig. 7 の細かな白い破線は, 縞模様の対応する凹部を示している. この写真から, 縞模様の凹部と凹部(黒い部分), 凸部と凸部

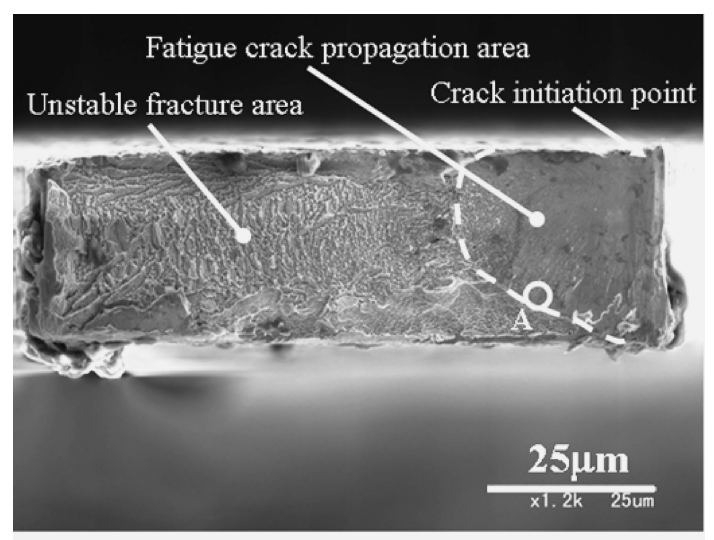

Fig. 4 Scanning electron micrograph on the fracture surface after $5.51 \times 10^{3}$ cycles under $2 \sigma_{\mathrm{a}} / \sigma_{\mathrm{w}}=1.04$.

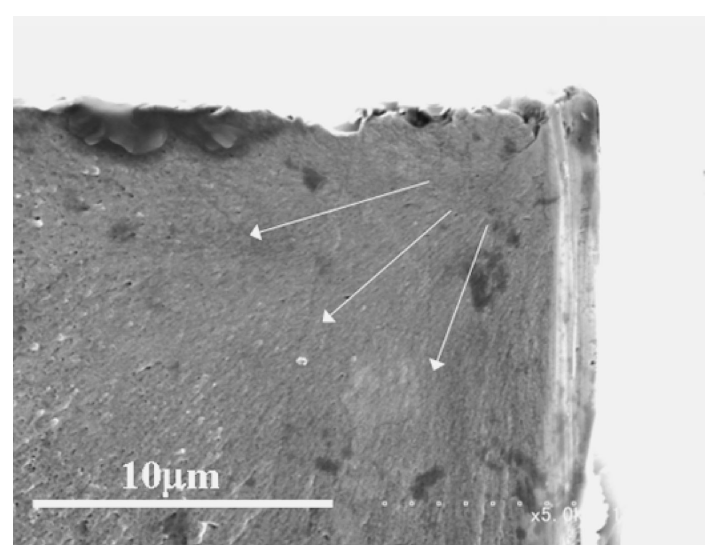

Fig. 5 Scanning electron micrograph near the crack initiation region on the fracture surface.
(白い部分)が対応しており, またき裂進展に伴う応力の増加 とともに縞間隔が広くなっており，さらに縞が互いに交わっ ていないことから，この縞模様はストライエーションと言え る.

このストライエーション間隔を疲労き裂伝ぱ速度 $(\mathrm{d} a / \mathrm{d} n)$ として，応力拡大係数範囲 $(\Delta K / E)$ との関係を求めた結果を 片振応力下の各種結晶合金の結果16) とともに Fig. 8 に示 す．ここで $\Delta K$ は，コーナー部の $1 / 4$ 楕円き裂の解17)を用 いて計算し, ヤング率 $E$ は引張試験の応力ひずみ線図の比 例域の勾配から求めた ${ }^{10)}$. ナノ結晶 $\mathrm{Ni}-\mathrm{W}$ 合金の $\mathrm{d} a / \mathrm{d} n-$ $\Delta K / E$ 関係は各種結晶合金の同関係の上縁より少し高速度 側にあることが分かる。これは, 本合金の疲労き裂伝ぱにお いてはき裂閉口が生じにくいことを示唆している．この原因 は, 本材料が高強度で延性が大きくないため塑性誘起き裂開 口が生じにくく, また, き裂発生起点近傍の低き裂伝ぱ速度 域に拈いても破面様相は極めてフラットであり，ストライ エーションが見られる領域の破面様相も比較的スムースであ り，破面あらさ誘起き裂閉口も生じにくいためと推測される.

結晶合金のパリス則の $m$ 值は, 通常 $2 \sim 4$ を示すことがよ く知られて抢り，本ナノ結晶合金の $m$ 值は約 2 を示してい る.ナノ結晶合金ではき裂は，後述するように Laird 機構に よりストライエーションを形成しながら成長していると見ら れ (Fig. 9, Fig. 10), この場合, $\mathrm{d} a / \mathrm{d} n$ は繰返しき裂先端開 口変位幅 $(\Delta \mathrm{CTOD})$ に比例し, これは有効応力拡大係数幅の 2 乗 $\left(\Delta K_{\mathrm{eff}}^{2} \cong \Delta K^{2}\right)$ に比例するため， $m$ 值は概略 2 を示した ものと考えられる.

Fig. 9 に試験片表面と破面を同時に見れる方向から撮影し た写真を示す。試験片表面には, 破面上でのストライエーシ ヨンに対応したせん断帯が確認できる. 同図に示すように, 試験片表面のせん断帯と荷重軸に垂直な破面のなす角度は約 $45^{\circ}$ であった。き裂先端における平面ひずみ下の最大せん断 応力方向は約 $68^{\circ}$ であり, $45^{\circ}$ となった理由は明らかではな いが，き裂先端の鈍化や試験片表面の応力状態の影響が考え られる。

Fig. 10 に延性材の結晶合金においてよく知られたストラ イエーション形成機構である Laird モデルの概略図 ${ }^{18)}$ を示 す．本合金のストライエーションと試験片表面のせん断帯の

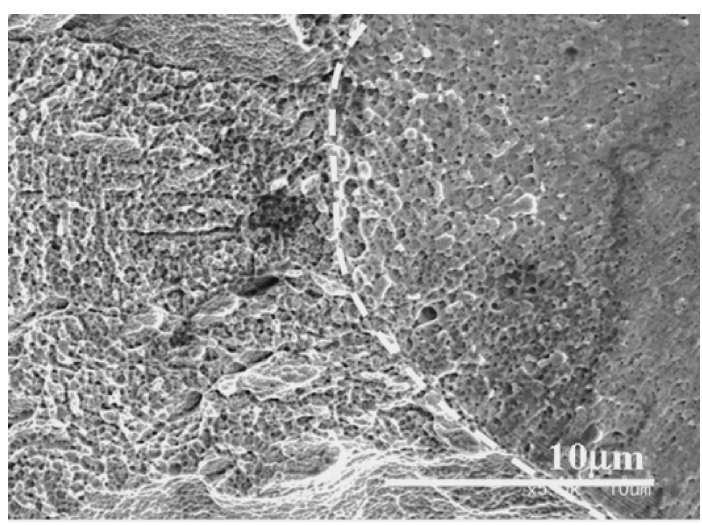

Fig. 6 Scanning electron micrograph near the boundary region between the fatigue and unstable fractures on the fracture surface. 


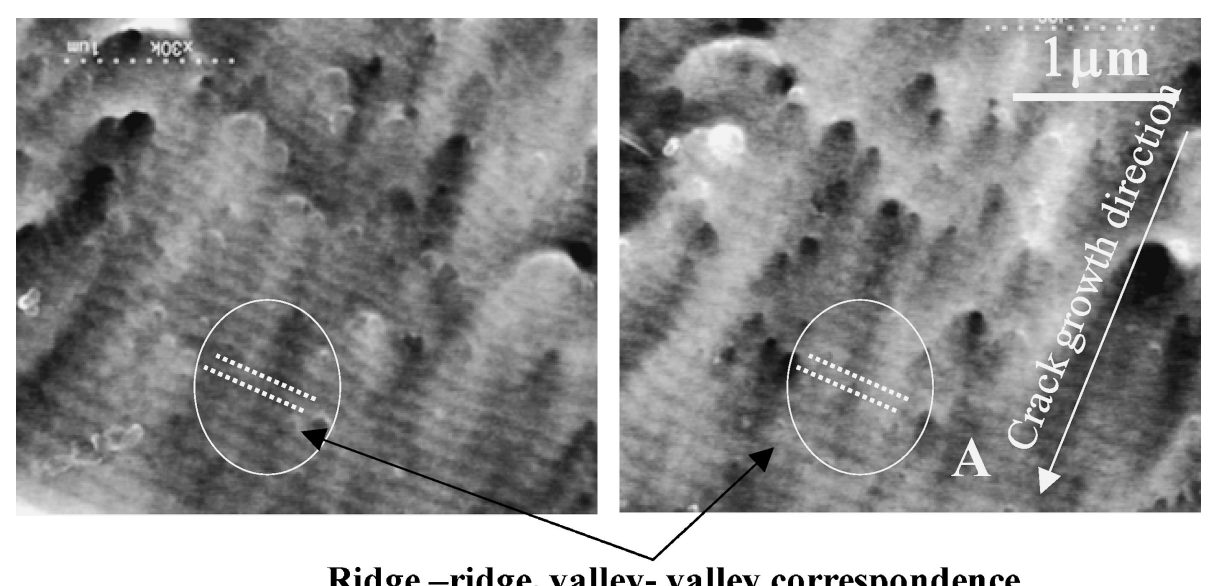

Ridge -ridge, valley- valley correspondence

Fig. 7 Matching scanning electron micrographs about striation on the fatigue crack propagation area.

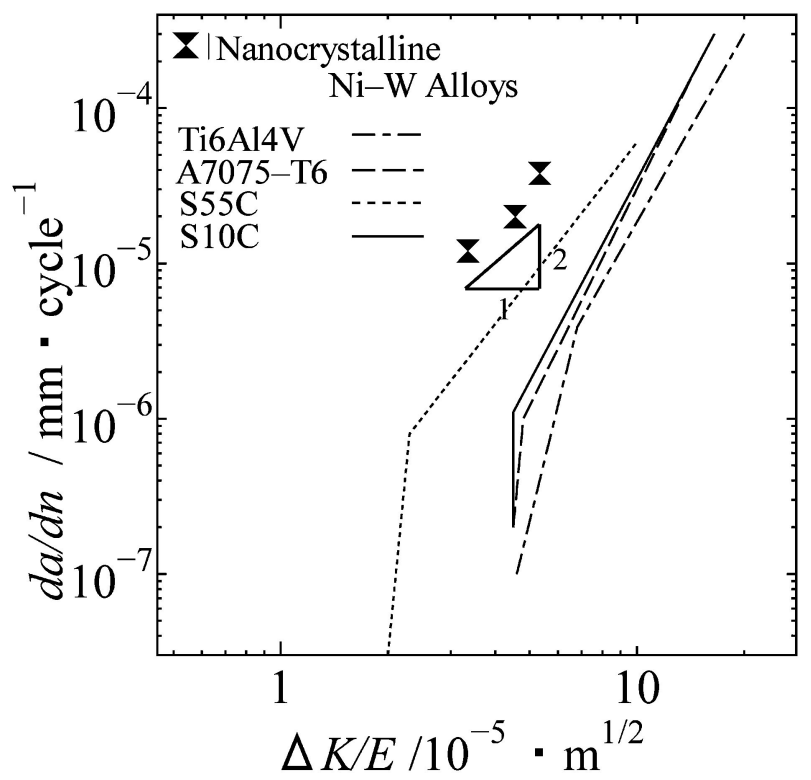

Fig. 8 Relationship between the $\mathrm{d} a / \mathrm{d} n$ and $\Delta K / E$.

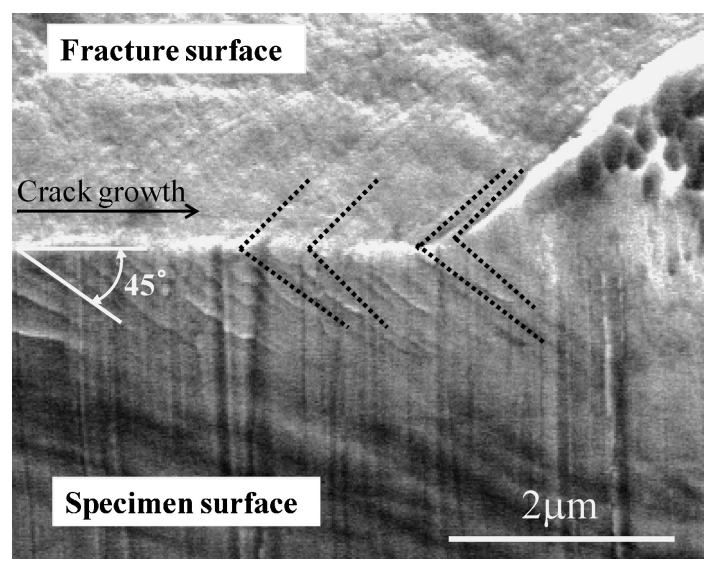

Fig. 9 Shear bands on the specimen surface corresponding to the striation on the fracture surface.

関係は，Fig. 10 で見られた Laird モデルと似ており，ナノ 結晶合金のストライエーションは Laird モデルと同様なメカ ニズムで形成されたものと考えられる.

Fig. 11 にき裂発生部付近の HR-SEM による拡大破面写
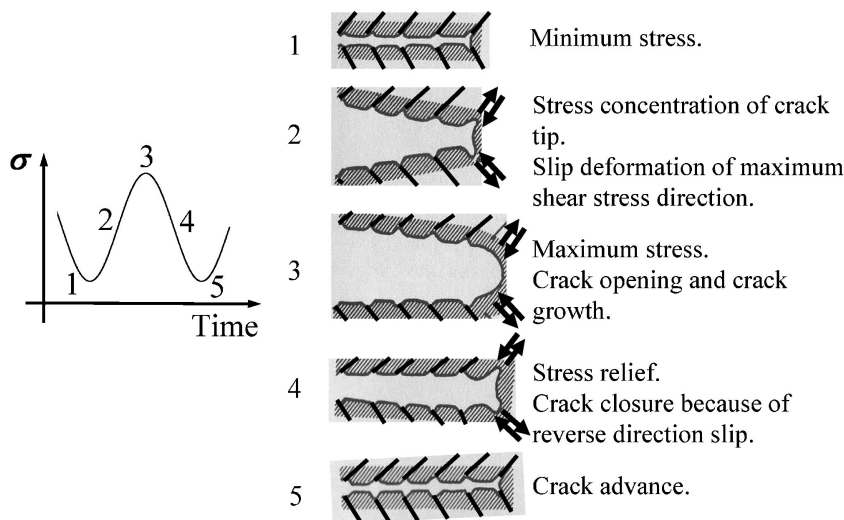

Fig. 10 Formation behavior of ductile striation.

真例を示す，図中の矢印はき裂伝ぱ方向を示しているＡ A 部の拡大写真において観察される粒はナノ結晶と見られる. ストライエーションは，この結晶粒径よりやや大きい $10 \mathrm{~nm}$ 程度の非常に細かな間隔 (ストライエーションの間隔 : SS) から見え始め，また，すべりは粒間で生じているように見受 けられる，粒界ですべるのは，ナノ結晶は寸法が小さく完全 結晶と考えられ，粒界は相対的に完全結晶より弱くせん断す べりを生じやすかったためと考えられる. ストライエーショ ンが粒径よりやや大きいSSになると見え始めたのは，SS が結晶粒サイズを超えることで完全結晶間の粒界に沿ってす ベることができためと思われる，さらにき裂が進展した B, $\mathrm{C}$ 部の拡大写真では, ストライエーションがより明瞭に見ら れる。これは，SSが大きくなると，より直線的に長く粒界 中をすべりやすくなるためと考えられる.

Fig. 12 に疲労き裂伝ぱ部に打けるディンプル状の模様に 注目したステレオマッチング写真を示す。実線の円で囲って いる比較的大きい模様に関しては凹と凸が対応しており，こ れらは粒状の界面で分離し形成されたものと見られる。一 方，破線の円で囲っている 4 個の比較的小さな浅いディン プル状の模様 (直径 $200 \mathrm{~nm}$ 程度)に関しては，凹と凹が対応 していることから，ディンプルと考えられる．しかし，ディ ンプル内を観察しても，通常の結晶合金で観察されるディン プルが形成されるのに必要な核となる介在物などは見られな 



Fig. 11 Scanning electron micrograph near the crack initiation region on the fracture surface.

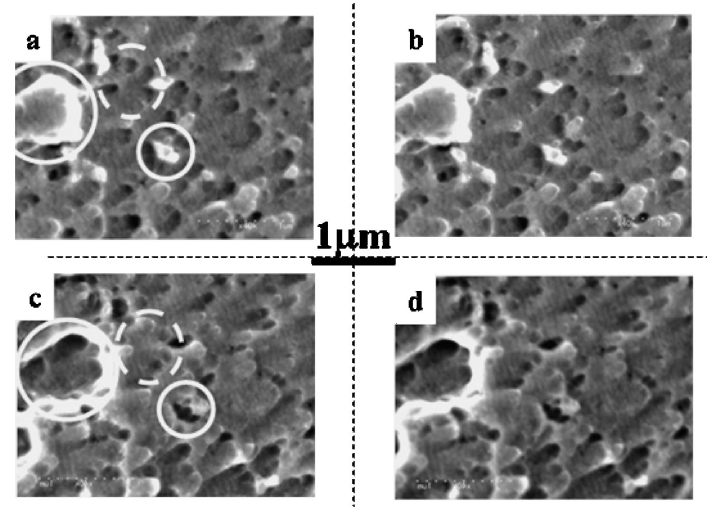

Fig. 12 Stereo-matching scanning electron micrographs about dimple pattern on the fatigue crack propagation area (ab, c-d stereo photographs, a-c, b-d matching photographs).

かった.これらのディンプルの観察結果は，ナノ結晶合金の 引張破断面のディンプルの観察結果と同様である. また，ナ ノ結晶合金の引張破面上のディンプルを HR-SEM で観察し た結果，Fig. 11 の疲労破面に見られたのと同様の数 $\mathrm{nm}$ か ら $20 \mathrm{~nm}$ 程度のナノ結晶とみられる粒が観察され, すべり はこの粒間で生じていると見られた．なお，ディンプルにつ いては凹部の底に核となる物は見られず，例えば粒界の三重 点でのすべりにより生じた空洞, あるいはナノ結晶自体が核 となって粒界すべりにより生じた可能性が考えられた ${ }^{10)}$.

以上のことから, ナノ結晶 $\mathrm{Ni}-\mathrm{W}$ 合金の疲労破壞は巨視 的には脆性破壊であるが，微視的には極めて延性的な破壊を していることが分かる. 通常の結晶合金に打けるストライ
エーションはよく知られているとおり結晶粒内のすべりによ り生じており，またディンプルも微小な析出物や介在物等を 核として 3 軸引張応力下で微小空洞が主として結晶粒内の すべりにより成長し生じている．しかし本合金は約 $6 \mathrm{~nm}$ の 完全結晶からなるナノ結晶合金であることから，粒内のすべ りは困難であり，ストライエーションおよびディンプルは粒 界すべりにより生じたと考えるのが Fig. 11 の観察結果およ びナノ結晶合金の引張破断面のディンプルの HR-SEM によ る観察結果と合わせ妥当と思われる. 加えて, ナノ結晶合金 の静的引張試験を実施した結果, 引張破断面は荷重軸方向に 対し約 $52^{\circ}$ 傾斜しており, 試験片表面では破面近傍でこれに 平行な多くのせん断帯が生じていた．約 $52^{\circ}$ は金属ガラスの 破断面の傾斜角度と一致して抢，このことからも，ナノ結 晶合金に生じたせん断帯はアモルファス構造と類似した構造 を有すると考えられる粒界中で生じたものと推測された ${ }^{10)}$.

本ナノ結晶合金の疲労は, 以上のような粒内の転位を通じ たすべりと異なり，抵抗のより大きい粒界すべりにより生じ ているとみられ，このため $\sigma_{\mathrm{w}}$ が大きくなったものと考えら れる. 今後, 疲労破面直下の組織を, 透過型電子顕微鏡を用 いて観察し，これらの形成機構を明らかにする必要がある。

境界前方領域のステレオマッチング観察を行った結果, 微 視的破面様相は全域が境界後方の疲労き裂伝ぱ部で見られた 模様と同様のディンプルであり，縞模様は見られなかった。

よって，境界前方領域は結晶合金と同様に不安定破懷部と考 えられた。

このようにナノ結晶 $\mathrm{Ni}-\mathrm{W}$ 合金は, 精密成形性と熱硬化 性を有し, 高強度, 高勒性であり, さらに今回, 高疲労限度 
を有することが明らかとなり，理想的な機械強度部材となり 得ることが示された.

\section{4. 結言}

ナノ結晶 $\mathrm{Ni}-\mathrm{W}$ 合金の疲労限度 $\left(\sigma_{\mathrm{w}}\right)$ は $2.1 \mathrm{GPa}$, 耐久比 $\left(\sigma_{\mathrm{w}} / \sigma_{\mathrm{B}}\right)$ は 0.74 であり, $\mathrm{Cr}-\mathrm{Mo}$ 鋼や合金工具鋼などの高強 度結晶合金の高疲労限度 $\left(\sigma_{\mathrm{w}}=\right.$ 約 $\left.1 \mathrm{GPa}\right)$ - 高耐久比 $\left(\sigma_{\mathrm{w}} / \sigma_{\mathrm{B}}\right.$ = 約 0.50$)$ 以上の高い值を示した.

ナノ結晶 $\mathrm{Ni}-\mathrm{W}$ 合金の疲労破面は，巨視的にはネッキン グを起こさず，荷重軸に対して垂直に破断していることから 脆性的な破面様相を示した. 疲労き裂発生起点はコーナー部 であり, 微視的破面様相は, き裂発生部付近は比較的平坦で 無特徵であり，き裂が進展するにつれてストライエーション が見られ，やがてディンプルも混在した様相を示し，延性的 な結晶合金の典型的な疲労破面様相とよく似ており，疲労破 壊であることを示した．ただし，これらのストライエーショ ンとディンプルは，通常の延性的な結晶合金と異なり，粒界 すべりにより形成されたものと推測された.

\section{文献}

1) L. Lu, M. L. Sui and K. Lu: Science 287 (2000) 1463-1466.

2) C. A. Schuh, T. G. Nie and T. Yamasaki: Scr. Mater. 46(2002) $735-740$.

3) H. S. Cho, W. G. Babcock, H. Last and K. J. Hemker: Abs. of $4^{\text {th }}$ Int. Workshop on High-Aspect-Ratio Micro-Structure Technology, (Barden-Baden, Germany, 2001) p. 201.
4) C. C. Koch, D. G. Morris, K. Lu and A. Inoue: MRS Bulletin 24 (1999) 54-58.

5) T. Yamasaki, P. Schloßmacher, K. Ehrlich and Y. Ogino: Nanostruct. Mater. 10(1998) 375-388.

6) T. Yamasaki, P. Schloßmacher, K. Ehrlich and Y. Ogino: Mater. Sci. Forum 269-272 (1998) 975-980.

7) T. Yamasaki: Scr. Mater. 44(2001) 1497-1502.

8) T. Yamasaki, H. Yokoyama and T. Fukami: Rev. Adv. Mater. Sci. 18(2008) 711-715.

9) T. Yamasaki, N. Oda, H. Matsuoka and T. Fukami: Mater. Sci. Eng. A 449-451(2007) 833-835.

10) K. Fujita, T. Suizu and T. Yamasaki: J. Japan Inst. Metals 75 (2011) 348-354

11) T. Nasu, M. Sakurai, T. Kamiyama, T. Usuke, O. Uemura, K. Tokumitsu and T. Yamasaki: Mater. Sci. Eng. A 375-377 (2004) 163-170.

12) H. Matsuoka, T. Yamasaki, Y. J. Zheng, T. Mitamura, M Terasawa and T. Fukami: Mater. Sci. Eng. A 449-451(2007) 790-793.

13) T. Yamasaki, M. Sonobe, K. Fujita, T. Kikuchi, H. J. Chang and D. H. Kim: Abstract of 17th Int. Symp. Metastable, Amorphous and Nanostructured Materials, (Swiss Federal Institute of Technology, ETH Zurich, Switzerland, 2010) p. 169

14) T. Tanaka (Ed.) et al.: Data Book on Fatigue Strength of Metallic Materials, 2, Code-Series 251-003, (The Soc. Mater. Sci., Japan, 1982) p. 1035.

15) T. Tanaka (Ed.) et al.: Data Book on Fatigue Strength of Metallic Materials, 2, Code-series 331-023, (The Soc. Mater. Sci., Japan, 1982) p. 1305

16) M. Jono (Ed.): Data Book on Fatigue Crack Growth Rates of Metallic Materials, (The Soc. Mater. Sci., Japan, 1983).

17) Y. Murakami (Chief-Ed.): Stress Intensity Factors Handbook, 2, (Committee on Fracture Mechanics, The Soc. Mater. Sci., Japan) pp. 712-715.

18) C. Laird: "The Influence of Metallurgical Structure on the Mechanisms of Fatigue Crack Propagation," in Fatigue Crack Propagation, (American Society for Testing and Materials, Philadelphia, Pa., 1967). 